\title{
Reflection on Ideological and Political Education in Foreign Language Teaching
}

\author{
Bianqi Sun ${ }^{1, *}$ \\ ${ }^{1}$ School of Basic Education, Beijing Institute of Graphic Communication, Beijing 102600, China \\ *Corresponding author. Email: sunbianqi@bigc.edu.cn
}

\begin{abstract}
The curriculum-based ideological and political education currently has a political and strategic connotation, which determines the implementation of morality cultivation and the fulfilment of value shaping tasks, integrating with knowledge learning and competence development. This paper analyses in detail the key factors concerning teaching staff, institutional design and student-centeredness development in ideological-political construction of the curriculum of foreign language education. Concrete suggestions are given to change the perspective of language instruction and talent cultivating mode in morality-strengthening education.
\end{abstract}

Keywords: Curriculum-based ideological and political education, Foreign language teaching, Morality cultivation, Institutional design, Student-centeredness.

\section{INTRODUCTION}

General Secretary Xi Jinping's exposition on curriculum of ideological and political education reveals that every link of educational undertakings revolves around the fundamental task of fostering virtue and morality in students, which is interrelated and constitutes the universal law of educational integrity and systematization. This universal rule is the fundamental guidance of educational theories and practices of various disciplines in the education system.

Giving full play to the global discourse ability of international senior foreign language talents in the new era and properly expressing the basic concept of a community with a shared future for mankind is a necessary condition for realizing permanent peace, consultation, joint construction and sharing of the future of mankind. Based on this goal, the theoretical research of foreign language education needs to systematically understand and redefine the task and orientation of foreign language education in the new era, and change the understanding of the traditional concept of foreign language education, and reform the existing discipline paradigm of foreign language education. The practical exploration of foreign language education needs to reform teaching methods, upgrade talent training mode and change the organization and management form of foreign language education.

For a long time, the debate on the positioning of instrumentality and humanism in foreign languages just reflects the development of foreign languages. Foreign language education is not only the product of internationalization, but also the product of times requirements. With the evolution of global history and international situation, the attribute and orientation of foreign language education change from the initial stage of being instrumental and communicative to ideological and humanistic, and then to national, international stage. This is a process of continuous progress, enhancement and expansion of foreign language. From language, literature, culture, translation, to international and regional studies, the connotation of foreign language discipline or foreign language education is becoming richer and richer, and its responsibility and mission are becoming more and more important, and the status of foreign language education means much more than before[1].

On this basis, it is required to have social moral quality, comply with social codes of conduct, understand China's national conditions, have a global vision, and have the discourse ability of connecting the world based on language ability and discipline ability. This is the epochal nature of 
foreign language education. It is the overall change driven by the need for foreign language education in the current era. It is a profound request made by general secretary $\mathrm{Xi}$ Jinping to foster foreign language talents, satisfying the needs of rapidly changing social development.

\section{TEACHING STAFF}

At present, most colleges and universities clearly require teachers to have some experience in studying and working abroad, and foreign language colleges and universities have higher requirements in this regard. Teachers of foreign language colleges and universities have more opportunities to obtain a degree in the target language country or visit the target language country for study, cooperative scientific research and exchange learning. The proportion of teachers who have studied and worked abroad is also higher than that of other colleges and universities, and the time of studying and working abroad is also relatively longer. What they learn abroad is basically the content of philosophy and social sciences, which is affected by the ideological and cultural of the target language countries, which also puts forward special requirements for the guidance of teachers' political and ideological education. In terms of curriculum ideological and political construction, such characteristics put forward higher requirements for both the management of foreign language colleges and ordinary teachers.

Thus, strengthening teacher training and enhancing teachers' awareness and ability of educating people becomes essential. General Secretary Xi Jinping points out that teachers carry the important task of disseminating knowledge, disseminating ideas, disseminating truth, shaping souls, shaping life and cultivating new people[2]. We must understand the great significance of strengthening the construction of teachers from a strategic perspective, and guide teachers to be good teachers with lofty ideals and beliefs, high moral sentiment, solid knowledge and benevolence. General Secretary Xi defined the responsibilities of teachers from a strategic perspective and put forward clear requirements for teachers in the new era. These requirements are particularly important for foreign language teachers who have long been exposed to western culture and receive western education. In China, there is famous saying: educators should receive education first. Therefore, first of all, schools should take different forms to improve the curriculum-based ideological and political ability of foreign language teachers. Through learning and discussion, they should unify their ideas, so that teachers can fully realize the importance of ideological and political education and teachers' responsibilities in curriculum-based ideological and political education. Second, they should organize teachers to carry out activities of academic discussion and exchange, so that teachers with outstanding curriculum ideological and political effects and popular with students can share experiences, wisdoms and the resources and their methods of ideological and political education to improve the curriculum-based ideological and political ability of foreign language teachers.

Teachers' ability to teach well is an important aspect of courses with ideological political elements, but teachers' words and deeds in their daily life must not be ignored. When the teachers' words and deeds are consistent, their classroom education can play its due effect. Teachers are invisible role models for students, and their words and deeds will have a subtle impact on students, serving as a role model for students to imitate. Therefore, teachers must be strict with their words and deeds. Only in this way can they silently and unconsciously educate people nonverbally and achieve a satisfying implicit effect of ideological and political education in their students.

\section{INSTITUTIONAL DESIGN}

In the education system, the textbooks are the basic means of knowledge training and ability development. It is necessary to strengthen the system construction to ensure the smooth implementation of ideological and political education. Curriculum-based ideological and political education is a systematic and comprehensive work of the all levels of schools. Besides the leaders and teachers' consciousness and awareness, it is absolutely necessary to have an institutional guarantee.

First, it is necessary to improve the system of textbook selection and development. Foreign language colleges and universities mostly use original foreign textbooks. Due to the differences in ideology and values, it is inevitable that there will be some improper contents in the course of teaching, and some may be against the morality cultivation. Therefore, we should control the quality of teaching materials, including the physical stuff and digital virtual medium. At the same time, we should also encourage teachers to develop characteristic teaching materials suitable for China's 
national conditions and the situation of each school, with the aim of integrating the content of curriculum-based ideological and political education into language education.

Second, we should improve the school-based training system for teachers and incorporate the improvement of curriculum-based ideological and political awareness and ability of professional teachers into the training of new teachers. Professional teachers are encouraged to demonstrate the concept of curriculum-based ideological and political education in teaching and scientific research, and appropriate rewards are given to teachers with outstanding curriculumbased ideological and political education. After all, teachers cultivate new generations of talents who are responsible for the rejuvenation of the Chinese nation and international talents with the ability to participate in global governance and leadership in different fields.

Third, it is necessary to improve the teaching organization and management system and incorporate the construction of curriculum-based ideological and political education into daily teaching and research activities. They regularly organize and discuss the design of curriculumbased ideological and political teaching scheme, paying attention to the collection of typical examples of curriculum ideological and political education, and carry out the fundamental task of strengthening morality.

Finally, it is suggested to improve the evaluation and assessment system to incorporate the construction of curriculum ideological and political education into the assessment of teaching, taking the effect of curriculum ideological and political education as one of the basis for teachers' professional title promotion, evaluation and award. We should improve the classroom teaching evaluation system so that classroom teaching evaluation not only fully reflects knowledge learning, but also reflects the value-leading effect and embodies the process of students' growth. In terms of curriculum ideological and political evaluation, it is necessary to include students' cognition, emotion and values, and reflect the humanity and diversity of evaluation, and stimulate teachers' initiative and enthusiasm in curriculumbased ideological and political evaluation with scientific evaluation. Courses with ideologicalpolitical elements require the integration of ideological and political content into nonideological-political courses. Teachers are obliged to practice the fundamental task of fostering virtue and morality in students, and integrate ideological political education into English teaching holistic education.

\section{STUDENT-CENTERED DEVELOPMENT}

In higher education, students are the centre and core of the teaching process. So the selection, compilation and evaluation of Ideological and political content of English teaching materials should focus on students' development, that is, the ideological and political content should be suitable for students' real learning situation and promote students' learning enthusiasm, and pay attention to students' ideological and political evaluation and feedback.

Firstly, the ideological and political content and its presentation form should be suitable for students' real social and cultural situation. In terms of content, the material should not be limited to the target language. We should combine the cultural background of Chinese English learners with human universal values, Chinese excellent ancient culture and the concept of scientific development in the new era. The ideological and political content should be compiled according to the ways and characteristics of students' access to resources in the information age, taking into account paper and electronic materials that are presented through text, images, audio and video, making good use of the official account and other platforms and media to share the learning materials with students.

Secondly, ideological and political work should be devoted to promoting students' cognitive and behavioural involvement. Students will actively participate in tasks, keep thinking and enjoy the learning process when they are in good condition. In order to enhance learners' input, on the one hand, the content compilation and exercise design should give attention to cultivating students' high-level thinking skills, so that students can realize and understand in the process of completing tasks or participating in teaching activities, internalize knowledge through understanding, analysis and thinking, and form critical thinking.

In terms of knowledge learning, in addition to setting the language knowledge that students need to master, it is highly recommended to clearly define what cultural concepts and values students need to understand. In terms of ability training, besides testing language skills, we should also 
evaluate students' ability to distinguish cultural situations and value orientations. The contents and methods of evaluation should be integrated into the construction of ideological and political content. Moreover, in view of the rapid development of the times and the uncertainty of students' learning situations and needs, the construction of ideological and political content is a dynamic development process, which requires teachers to pay close attention to students' feedback. Regretfully, till now there has been no ideal way to assess the compound effect of morality cultivation.

It is required to obtain students' learning data through the network teaching management platform, and understand their learning, and judge whether they practice ideological and political elements by observing students' daily behaviour to adjust and improve the construction and use of materials. Whatever we do, we should always keep in mind that student-centeredness is the core of all-level education, and arrangements catering to the practical needs are highly desired and promoted[3].

\section{CONCLUSION}

The goal of foreign language education is to cultivate talents who can take on the great task of national rejuvenation, and to reserve international talents who participate in global behaviour and global governance and have leadership[4]. To achieve this goal, we need to change our traditional concept of foreign language education and improve the positioning and importance of foreign language education. Foreign language ability is not only an individual's language ability, but also a country's language ability. Building global discourse ability with strong national language ability and fully expressing the ideal of community with a shared future for mankind is the ideal way to achieve permanent peace for mankind. Foreign language education is needed to cultivate more outstanding talents with global discourse ability, who can participate in global governance, national construction and national rejuvenation. Facing this historical mission, college students are duty bound and have a long way to go. It needs to make efforts to explore and undertake the reform of the teaching paradigm of foreign language education, and explore good strategies for cultivating people to improve the talent training mode and implement the overall requirements of the cultivation of excellent talents, and make new contributions to the realization of the CPC's "two centenary" goals [The two goals are to complete a moderately prosperous society in all respects by the centenary of the CPC (founded in 1921), and to build China into a modern socialist country that is prosperous, strong, democratic, culturally advanced, and harmonious by the centenary of the People's Republic of China (founded in 1949).] and the great Chinese dream of national rejuvenation.

Exploring the ideological and political construction of foreign language courses is carried out according to this requirement and perspective. For us, we should keep up with the pace of the times and keep learning so that we will not be eliminated by the times. Therefore, every foreign language educator should strive to improve his political position and conviction, update ideas, learn new knowledge, face new problems and complete his new career. The ideological and political construction of foreign language curriculum is a long-term and systematic project, which is vital for the survival of a nation. In the new era, doing a good job in the ideological and political construction of foreign language curriculum is a challenge to every foreign language educator. At present, we need to first deeply understand the connotation of ideological and political curriculum and its integration with courses with ideological and political elements, and understand its significance and meaning, and improve our theoretical level and political position. To be a qualified education, it is necessary to upgrade the understanding of language education. Second, educations should find a breakthrough point and explore the concrete implementation of morality cultivation. Only in this way can we do a good job in the ideological and political construction of foreign language courses and cultivate qualified foreign language talents needed by the country in the new era. Well-rounded talents are to be cultivated with the implementation of value shaping tasks and integrated with knowledge learning and competence development.

\section{AUTHORS' CONTRIBUTIONS}

This paper is independently completed by Bianqi Sun.

\section{ACKNOWLEDGMENTS}

This research is supported by program of Postgraduate Discipline Construction of BIGC (21090121030); Program of Quality Improvement of BIGC (22150120015). 


\section{REFERENCES}

[1] He Lianzhen. New requirements of College English Teaching in the new era - The Basis and Key Points of Revision of College English Teaching Guidelines [J]. Foreign Language World, 2020,(4) : 13 - 18.

[2] Xi Jinping. Speech on Ideological and Political Work in Colleges and Universities at the National Conference [OL] http://www.xinhuanet.com// politics/201612/08/c_ 1120082577.htm (visit Time: September 15, 2021)

[3] Ministry of Education of the People's Republic of China, Comments on the Reform of Science Education and Teaching to Improve the Quality of Talent Training in an All-round Way [OL] http://www.moe.gov.cn/srcsite/A08/s7056/201 910/t20191011_ 402759.html (visit Time: September 15, 2021)

[4] Guidelines for Curriculum-based Ideological and Political Construction of in Colleges and Universities (2020), May 28, 2004 http://www.gov.cn/zhengce/zhengceku/202006/06/content_5517606.htm. (Date of visit: September 15, 2021) 